\title{
Intracavernous Injection of Vasoactive Drugs, an Alternative for Treating Impotence in Spinal Cord Injury Patients
}

J. J. Wyndaele, M.D., ${ }^{1,2}$ J. M. de Meyer, M.D., ${ }^{1}$ W. A. de Sy, M.D. ${ }^{1}$ and H. Claessens, M.D. ${ }^{2}$

${ }^{1}$ Department of Urology and ${ }^{2}$ Rehabilitation Centre, Academical Hospital, State University, Ghent, Belgium

\begin{abstract}
Summary
We report on our results with the intracavernous injection and self-injection of papaverine-phentolamine in a group of spinal cord injury patients with erectile impotence. This technique offers the possibility of achieving a full erection which continues for a few hours and disappears afterwards. In our limited experience no major complications have occurred. If our findings are confirmed, in future, the self-injection technique may become a valuable alternative to implanting a prosthesis in impotent paraplegics and tetraplegics.
\end{abstract}

Key words: Spinal cord lesion; Sexual impotence; Intracavernous injection.

\section{Introduction}

In male patients with spinal cord injury (SCI) erections are abolished in at least $23^{\circ}{ }_{0}$ (Jouannet, et al., 1981). Whilst in patients with upper motor neuron lesions (UMNL) erectile potency may be preserved in up to $95^{\circ}{ }_{0}$, in those with lower motor neuron lesions (LMNL) psychogenic erection was found in only $24^{\circ}{ }_{0}^{\circ}$ and reflex erection in only $12^{\circ}{ }_{0}$ (Comarr, 1970). Especially in this last group of SCI patients, with complete destruction of the nerves involved in sexual function, erectile impotence could only be treated previously by implanting a rod-type or inflatable type of penile prosthesis. Recently it has been shown that the injection of certain vaso-active drugs into the corpus cavernosum could provoke an erection (Brindley, 1983). One year ago we started to treat erectile impotence in some of our SCI patients with the injection of phentolaminepapaverine into one corpus cavernosum. This paper deals with our first observations.

\section{Patients and methods}

In 12 SCI patients with erectile impotence the technique of intracavernous injection was used. Seven patients had a LMN lesion (one incomplete), and five patients a UMN lesion (one incomplete). Their mean age was 27 years. 
The injection was done with a 25 gauge needle transcutaneously into one corpus cavernosum. The injection speed was slow (1-2 minutes). After withdrawal of the needle, firm compression of the injection site for 5 minutes was done to avoid bleeding and the formation of a subcutaneous haematoma. In all patients, the heart rate and blood pressure were controlled throughout the test. Patients were asked to report dizziness and any other symptom possibly related to the injection. The appearance of erection was noticed and the firmness of the cavernosus swelling was estimated by palpation and bending the penile shaft. The length of time that the erection lasted was also noted. The first six patients were kept under control at the urological department for as long as the erection lasted. The last six patients returned home 1 hour after their injection and contacted us afterwards by telephone to discuss the results. They were instructed to come back to the hospital if the erection persisted for more than 6 hours.

Initially a dose of $10 \mathrm{mg}$ papaverine plus $2 \mathrm{mg}$ phentolamine was used. As this gave an unsatisfactory result in the majority of patients, the dose was gradually increased on consecutive applications until a good result was obtained. An interval of at least 1 week between the injections was observed. If patients wished to be considered for longterm treatment, we taught the self-injection technique to the patient or to his wife. As soon as full erection was obtained by self-injection carried out at our department, the treatment was continued at home. For ambulatory use we had disposable syringes, with the adequate dose of medication, prepared by our hospital pharmacy. The syringes were delivered in sterile individual packages and kept at home in a dark-cool place (usually the refrigerator). Dissociation tests performed by the pharmacy laboratory proved that the medication could preserve its action for at least 1 month, if properly kept.

Each patient was given five syringes to be used during a period of 1 month. After each month patients were expected to return to our department for medical control and a new prescription.

\section{Results}

The injection of papaverine-phentolamine gave a full erection in nine patients after the optimal dose had been individually determined. In two patients the test is still incomplete (Table 1). In one patient the injection was carried out one year after the removal of a penile prosthesis. This patient obtained only a moderate swelling of the penis with the injection technique. In none of the patients was swelling of the glans penis noticed. The erection appeared usually within 10 minutes and lasted in most patients for \pm 3 hours (one to six hours). Self-injection was learned by four patients and by the wives of three other patients. Self-injection at home was done by six patients. (Table 2).

Regular coitus was possible in three of these patients. Full erections were obtained regularly with an injection during a follow-up period of 2 to 6 months.

To date, no major complications have occurred. In one patient the first injection of $5 \mathrm{mg}$ phentolamine and $30 \mathrm{mg}$ papaverine produced priapism. Puncture of the corpus cavernosum and aspiration of the clotted blood was performed 12 hours after the injection had been given. One week later a new 
Table 1 Result of different doses of medication used for intracavernosus injection

\begin{tabular}{ccc}
\hline $\begin{array}{c}\text { Dose used } \\
\text { Phentol. Papaver. }\end{array}$ & $\begin{array}{c}\text { Total No. Patients } \\
\text { in which this Dose } \\
\text { was used }\end{array}$ & $\begin{array}{c}\text { No. of Patients with } \\
\text { Full Erection }\end{array}$ \\
\hline $2 \mathrm{mg}+10 \mathrm{mg}$ & 6 & 1 \\
$2 \mathrm{mg}+20 \mathrm{mg}$ & 1 & 0 \\
$5 \mathrm{mg}+10 \mathrm{mg}$ & 2 & 2 \\
$5 \mathrm{mg}+20 \mathrm{mg}$ & 3 & 1 (priapism) \\
$5 \mathrm{mg}+20 \mathrm{mg}$ & 1 & 0 \\
$10 \mathrm{mg}+20 \mathrm{mg}$ & 1 & 3 \\
$10 \mathrm{mg}+30 \mathrm{mg}$ & 1 & 1 \\
$10 \mathrm{mg}+40 \mathrm{mg}$ & 4 & - \\
$10 \mathrm{mg}+80 \mathrm{mg}$ & 1 & - \\
Test Incomplete & & - \\
$2 \mathrm{mg}+20 \mathrm{mg}$ & 1 & - \\
$5 \mathrm{mg}+20 \mathrm{mg}$ & 1 & \\
After Removal Prosthesis & & 1 \\
$5 \mathrm{mg}+40 \mathrm{mg}$ & & \\
\hline
\end{tabular}

Table 2 Results of self-injection at home

\begin{tabular}{lcccccc}
\hline Patient & $\begin{array}{c}\text { Spinal Cord } \\
\text { Lesion }\end{array}$ & $\begin{array}{c}\text { Injection } \\
\text { Done By }\end{array}$ & $\begin{array}{c}\text { Dose (mg) } \\
\text { Phent. Papa. }\end{array}$ & $\begin{array}{c}\text { Full } \\
\text { Erection }\end{array}$ & Coitus & $\begin{array}{c}\text { Period } \\
\text { Follow-up } \\
\text { (Months) }\end{array}$ \\
\hline 2 & C2-C3 & partner & $10+80$ & + & + & 2 \\
5 & D12 & self & $10+40$ & + & no partner & 3 \\
6 & D9 & partner & $5+20$ & + & - & 4 \\
7 & D12 & self & $10+40$ & + & + & 3 \\
8 & D12 & partner & $5+20$ & + & + & 2 \\
11 & L2 & self & $2+10$ & + & no partner & 6 \\
\hline
\end{tabular}

injection at a lower dose gave a full erection that remained for $3 \frac{1}{2}$ hours. Consecutive injections subsequently produced a full erection.

In two patients a subcutaneous haemorrhage occurred due to insufficient compression after injection; conservative local treatment was given and was effective.

In one patient a subcutaneous injection of the drug resulted in oedema of the prepuce that lasted for 2 days..

\section{Discussion}

Sexuality is an important motive in human life and the sense of sexual adequacy is a major factor in the rehabilitation of SCI patients.

After a spinal cord lesion erectile impotence can occur and treatment of this dysfunction with the implantation of a penile prosthesis has found wide acceptance.

Rod-type prostheses are implanted with an overall success rate of more than $94^{\circ}{ }_{0}$ with few complications (Small, 1983; Finney, 1983; Jonas, 1983). The 
diameter and length of the penis are sufficient for intercourse, but the diameter is not as large as occurs with a normal erection, and the erection is permanent. Inflatable penile prostheses have the advantage that erection is not permanent, but this type of prosthesis is expensive and a $48^{\circ}{ }_{0}$, rate of mechanical failure has been found on longterm follow up (Fallon et al., 1984).

This incited us to try the injection of vasoactive drugs into the corpus cavernosum for the treatment of erectile impotence in SCI patients.

Brindley (1983) used phenoxybenzamine and had good results in two of the three SCI patients to whom this product was administered. Others (Virag, 1984; Zorgniotti and Lefleur, 1985) have published good results with papaverine and papaverine-phentolamine injection in impotent patients with mainly a vascular disease. Papaverine is known to be a nonspecific smooth muscle relaxant that produces vasodilatation, the mode of action of which is not clear (Nickerson, 1970 (1)). Phentolamine produces vasodilatation through a relatively transient but potent $\alpha$-adrenergic blockade (Nickerson, 1970 (2)).

A combination of these two drugs produced a full erection of the penis in almost all of our patients.

No swelling of the glans penis occurred due to the different vascularisation of the corpus cavernosum and the corpus spongiosum. The length of the erected penis was a little shorter than normal. This however was not an obstacle to intercourse and the penis diameter was as large as occurs with a normal erection. No major complications occurred. The method is safe: both drugs are intended for eventual intravenous administration and the dose used is small.

Self-injection at home has been promising in our small experience and the self-injection technique was easily learned by patients and their relatives. The dose to be injected should be individually determined and gradually raised. This lowers the risk of priapism. If all patients are instructed to contact their urologist should the erection persist for more than 6 hours after injection, proper treatment can be given and no definite harm will be seen. Further injections at a lower dose can give a full, non-lasting, erection afterwards. It is possible that intracavernous injection does some mechanical damage that may be cumulative. Longterm results are needed to ascertain this.

We think that self-injection may become a valuable alternative for a penile prosthesis in some SCI patients. We consider that this method is contra-indicated if full erection can be obtained by any other conservative means, if patients have haematological problems and if abuse or misuse are expected or experienced. As the medication may have some influence on liver function, blood tests should be done regularly. The liver function remained normal in two of our patients after three and six months of use. The same result was found by Zorgniotti and Lefleur in three patients with a follow-up of 9 months.

One year after removal of a penile prosthesis in a patient the injection gave only a moderate swelling of the penis. This might have been dose-dependent as Zorgniotti and Lefleur had a good result in a similar patient.

Further experience with this method in a very large group of patients is necessary to get irrefutable conclusions, especially concerning longterm results.

\section{Résumé}

Nous rapportons nos résultats concernant le traitement chez 12 patients à lésion médullaire, de 
l'impuissance sexuelle par l'injection et l'autoinjection de papaverine et phentolamine dans le corps caverneux.

Cette technique permet de provoquer une érection qui persiste pendant quelques heures pour disparaître après.

Nous n'avons pas vu de complications majeures mais notre experience est encore limitée.

Si nos résultats actuels se confirment dans l'avenir, l'auto-injection peut devenir une alternative valable à l'implantation de prothèses peniennes chez certains para- et tetraplégiques.

\section{Zusammenfassung}

Wir berichten über unsere Ergebnisse mit Injection und Selbstinjektion mit Papaverin-Phentolamin bei einer Gruppe von querschnittgelähmten Patienten mit erektiler Impotenz. Die Technik bietet die Möglichkeit des Zustandebringens einer völligen Erketion die einige Stunden anhält und dann nachlässt.

Im Rahmen unserer beschränktden Erfahrung haben wir keine wichtige Komplikationen festgestellt.

Falls die Ergebnisse künftighin genauso gut bleiben, kann diese Selbstinjektionstecknik eine wertvolle Alternativmöglichkeit für die Penisprothesen bei der Behandlung von Impotenz bei Paraund Tetraplegikern sein.

\section{References}

BRINDley GS 1983 Cavernosal Alfa-Blockade. A new technique for investigating and treating erectile impotence. Brit. J. Physiat. 143:332-337.

COMARR AE 1970 Sexual function among patients with spinal cord injury. Urologia Internationalis 25:134-168.

Fallon B, Rosenberg S, Culp DA 1984 Longterm follow-up in patients with an inflatable penile prosthesis. Journal of Urology 132:270-271.

FINNEY RP 1983 Finney-flexirod prosthesis. In: Controversies in Neuro-Urology. Edited by Barrett D. and Wein A., Churchill Livingstone, New York, 508-520.

Jonas U 1983 Silicone-Silber Penile Prosthesis. In: Controversies in Neuro-Urology. Edited by Barrett D. and Wein A., Churchill Livingstone, New York, 521-530.

Jouannet P, Chapelle PA, Francois N, et al., 1981 La paraplégie chez l'adulte et chez l'enfant. Editor Maury M, Flammarion Médecine-Sciences, Paris, p. 410.

NiCKERSON M 1970 (1) Drugs inhibiting adrenergic nerves and structures innervated by them. In: The pharmacological basis of therapeutics. Edited by Goodman L and Gilman A, MacMillan Company, New York, 26:549-584.

NiCKERSON M 1970 (2) Vasodilator drugs. In: The pharmacological basis of therapeutics.

Edited by Goodman L and Gilman A, Macmillan Company, New York, 34:745-763.

Small MP 1983 The Small-Carrion Penile implant. In: Controversies in Neuro-Urology. Edited by Barrett D and Wein A, Churchill Livingstone, New York, 491-508.

VIRAG R 1984 The treatment of angiogenic impotence. International Angiology, 3:275-279.

ZORGNIOTTI AW and LEFLEUR RS 1985 Autoinjection of the corpus cavernosum with a vasoactive drug combination for vasculogenic impotence. Journal of Urology 133:39-41. 